\title{
SYNTHESIS AND BIOLOGICAL ACTIVITY OF A NEW CEPHALOSPORIN, BMY-28232 AND ITS PRODRUG-TYPE ESTERS FOR ORAL USE
}

\author{
Hajime Kamachi, Yukio Narita, TakaAki Okita, Yoshio Abe, \\ Seim Iimura, Kozo Tomatsu ${ }^{\dagger}$, Tetsuro Yamasaki, Jun Okumura, \\ Takayuki Naito, Toshikazu OKI and Hiroshi KaWaguchi \\ Bristol-Myers Research Institute, Ltd., Tokyo Research Center, \\ 2-9-3 Shimo-meguro, Meguro-ku, Tokyo 153, Japan
}

(Received for publication April 9, 1988)

\begin{abstract}
The synthesis and structure-activity relationships of $7-[(Z)-2-(2$-aminothiazol-4-yl)-2hydroxyiminoacetamido]-3-[(Z)-1-propenyl]-3-cephem-4-carboxylic acid (BMY-28232), its 3alkenyl analogs $(6$ and 7$)$ and $O$-substituted derivatives of the oxyimino moiety $(10)$ are described, as well as the oral pharmacokinetics and in vivo activities of the 1-acetoxyethyl ester of BMY-28232 (BMY-28271) and its analogous esters (11). The 3-alkenyl groups were introduced by the Wittig reaction of the ylide (2) prepared from the 3-chloromethyl cephem (1) to afford the $Z$ (main) and $E$ (minor) isomers regarding the 3 -side chain. The $O$-substituted derivatives (10) were prepared by $7-N$-acylation of the 7 -amino cephem (4a) with the corresponding $O$-substituted side chain acids $(\mathbf{8})$. The prodrug esters $(\mathbf{1 1})$ were prepared by esterification of BMY-28232 with an appropriate halide. BMY-28232 was the most active among the 3-alkenyl analogs tested against Gram-negative organisms and much more active than the $O$-substituted derivatives against Gram-positive bacteria. BMY-28271 showed good oral bioavailability $(66 \%)$ and good in vivo efficacy in mice against infections of Staphylococcus aureus Smith $\left(\mathrm{PD}_{50}, 0.68 \mathrm{mg} / \mathrm{kg}\right)$ and Escherichia coli Juhl $(0.54 \mathrm{mg} / \mathrm{kg})$.
\end{abstract}

Since the discovery of cefuroxime axetil ${ }^{11}$, a number of prodrug-type cephalosporin esters ${ }^{2-8)}$ possessing an aminothiazole moiety at the $\mathrm{C}-7$ position of the cephem nucleus have been reported as orally active cephalosporins. They are mostly different from one another in the C-3 side chain.

Previously we have found 3-alkenyl cephalosporins ${ }^{\theta}$ in the cephalexin-cefadroxil series showing good oral absorbability and selected a $3-(Z)$-propenyl derivative, BMY-28100,10), for clinical evaluation. In the course of our research program exploring broad spectrum oral cephalosporins, we applied the C-3 alkenyl side chain to the aminothiazole cephalosporins and identified a new 3-( $Z$ )propenylcephalosporin, BMY-28232 (Fig. 1), which showed a well-balanced, broad antibacterial spectrum against Gram-positive and Gram-negative organisms including $\beta$-lactamase-producing strains. BMY-28232 was orally absorbed in mice to some extent. To improve its oral absorption, several prodrug-type esters of BMY-28232 were prepared, among which BMY-28271 (Fig. 1), the acetoxyethyl ester of BMY-28232, was selected for further evaluation in view of its excellent oral absorption and good in vivo activity ${ }^{\dagger \dagger}$.

This paper describes the synthesis and the structure-activity relationships of BMY-28232

Fig. 1. BMY-28232 and BMY-28271.<smiles>C/C=C\C1=C(C(=O)O)N2C(=O)C(NC(=O)/C(=N/O)c3csc(N)n3)C2SC1</smiles>

BMY-28232 $\mathrm{R}=\mathrm{H}$

BMY-28271 $\mathrm{R}=\mathrm{CHOCOCH}_{3}$ $\stackrel{\mathrm{C}}{\mathrm{CH}}$

$\uparrow$ Deceased.

tt A part of this workes has been presented at the 27th Intersci. Conf. on Antimicrob. Agents Chemother. Meeting, Abst. No. 806, New York, 1987. 
and its analogs. The oral pharmacokinetics and oral in vivo activities of BMY-28271 and its analogous esters are also discussed.

\section{Chemistry}

The 3-propenylcephalosporin acid, (BMY-28232, 6a) was prepared by the synthetic route shown in Scheme 1. Diphenylmethyl 7-benzylideneamino-3-chloromethyl-3-cephem-4-carboxylate (1) ${ }^{112}$ was treated with triphenylphosphine followed by aqueous $\mathrm{Na}_{2} \mathrm{CO}_{3}$ to give the ylide 2 in $81 \%$ yield. The Wittig reaction of 2 with acetaldehyde was carried out to afford the reaction product 3 , which was, without isolation, treated with Girard $\mathrm{T}$ reagent to give compound $4 \mathrm{a}$ in $71 \%$ yield as colorless needles. The HPLC study (ODS, 70\% MeOH - pH 7 buffer) indicated that $4 a$ was a mixture of two components (85:15) with retention time at 5.7 minutes for the major component and 7.1 minutes for the minor one. The ${ }^{1} \mathrm{H}$ NMR spectrum of $4 \mathrm{a}$ showed a doublet at $6.23 \mathrm{ppm}(J=12 \mathrm{~Hz})$ indicating that the reaction gave predominantly the $c i$ s isomer in regard to the 3-side chain. Since it was difficult to separate these isomers by crystallization or column chromatography in this stage, the product was used for the next step without separation of the isomers. Compound $4 \mathrm{a}$ was acylated with $(Z)-2-$ (2-tritylaminothiazol-4-yl)-2-trityloxyiminoacetic acid ${ }^{12)}$ by the active ester method using 1-hydroxybenzotriazole to afford $\mathbf{5 a}$ in $98 \%$ yield after column chromatography. Deblocking of $\mathbf{5 a}$ with $\mathrm{HCOOH}-\mathrm{HCl}$ was followed by chromatography on a column of reverse phase silica gel to separate the $Z$ isomer (6a) in $33 \%$ yield and its $E$ isomer (7a) in $4 \%$ yield. The 3-butenyl and 3-vinyl analogs were similarly prepared from 2 . The Wittig reaction of $\mathbf{2}$ with propionaldehyde and formaldehyde

Scheme 1. Synthesis of 3-alkenyl cephalosporins (6 and 7).

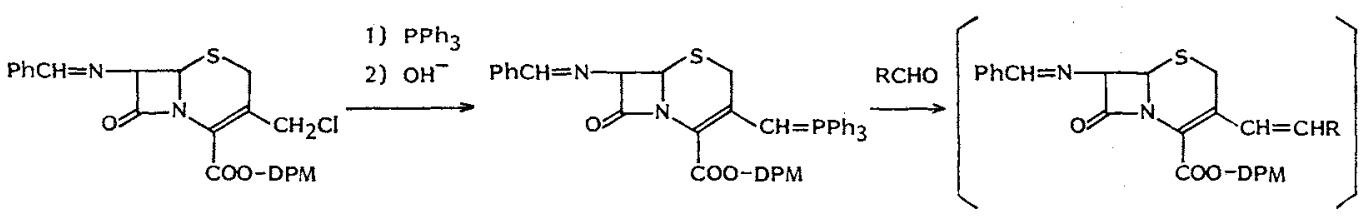

1 2

3

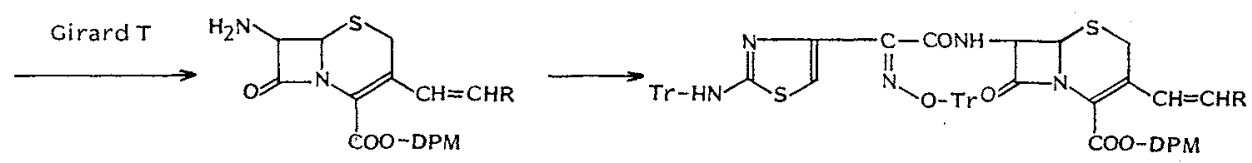

$$
\begin{array}{ll}
4 \mathbf{a} \mathrm{R}=\mathrm{CH}_{3} & \text { 5a } \mathrm{R}=\mathrm{CH}_{3} \\
4 \mathbf{b} \mathrm{R}=\mathrm{C}_{2} \mathrm{H}_{5} & 5 \mathrm{~b} \mathrm{R}=\mathrm{C}_{2} \mathrm{H}_{5} \\
4 \mathbf{c ~ R}=\mathrm{H} & \text { 5c } \mathrm{R}=\mathrm{H}
\end{array}
$$

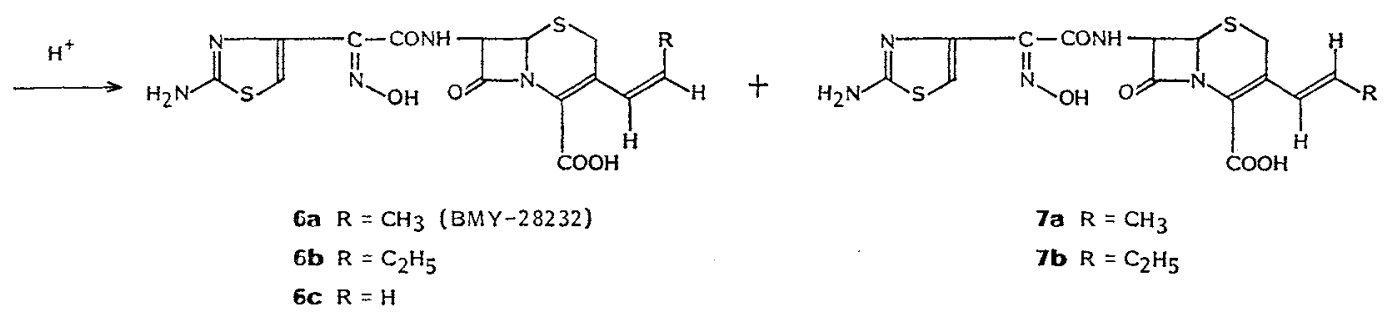


Table 1. Yields, mp, UV, ${ }^{1} \mathrm{H}$ NMR and mass data of 3-alkenyl cephalosporins (6 and 7).
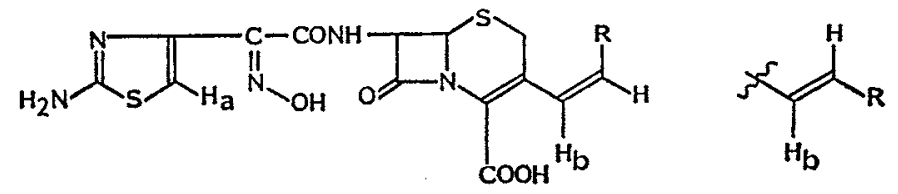

6

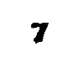

\begin{tabular}{|c|c|c|c|c|c|c|c|c|c|c|c|}
\hline \multirow{2}{*}{ Compound } & \multirow{2}{*}{$\mathbf{R}$} & \multirow{2}{*}{$\begin{array}{l}\text { Yield } \\
(\%)\end{array}$} & \multirow{2}{*}{$\begin{array}{c}\mathrm{MP} \\
\left({ }^{\circ} \mathrm{C}, \mathrm{dec}\right)\end{array}$} & \multirow{2}{*}{$\mathrm{UV} \lambda_{\max } \mathrm{nm}(\varepsilon)^{\mathrm{a}}$} & \multicolumn{6}{|c|}{${ }^{1} \mathrm{H} \mathrm{NMR}\left(80 \mathrm{MHz}, \delta\right.$ in $\left.\mathrm{D}_{2} \mathrm{O}\left(+\mathrm{NaHCO}_{3}\right)\right)$} & \multirow{2}{*}{$\begin{array}{c}\text { Mass } \\
(m / z) \\
(\mathrm{M}+1)^{+}\end{array}$} \\
\hline & & & & & $2-\mathrm{H}^{\mathrm{b}}$ & $6-\mathrm{H}^{\mathrm{e}}$ & $7-\mathrm{H}^{\mathrm{e}}$ & $\mathrm{H}_{2}{ }^{\mathrm{d}}$ & $\mathrm{H}_{\mathrm{b}}{ }^{\mathrm{e}}$ & $\mathbf{R}$ & \\
\hline $6 \mathbf{a}$ & $\mathrm{CH}_{8}$ & 33 & 170 & $\begin{array}{l}225(18,400) \\
282(15,200)\end{array}$ & 3.56 & 5.35 & 5.90 & 7.06 & 6.02 & $1.73\left(\mathrm{CH}_{3}\right)$ & 410 \\
\hline $7 \mathbf{a}$ & $\mathrm{CH}_{3}$ & 4 & 200 & $\begin{array}{l}223(20,000) \\
290(21,000)\end{array}$ & 3.69 & 5.25 & 5.83 & 6.97 & 6.55 & $1.85\left(\mathrm{CH}_{3}\right)$ & 410 \\
\hline $6 \mathbf{b}$ & $\mathrm{C}_{2} \mathrm{H}_{5}$ & 23 & 170 & $\begin{array}{l}223(17,000) \\
281(15,300)\end{array}$ & 3.55 & 5.34 & 5.90 & 7.07 & 6.00 & $\begin{array}{l}1.05\left(\mathrm{CH}_{3}\right) \\
2.12\left(\mathrm{CH}_{2}\right)\end{array}$ & 424 \\
\hline $7 \mathrm{~b}$ & $\mathrm{C}_{2} \mathrm{H}_{5}$ & 3 & 170 & $\begin{array}{l}223(19,400) \\
290(19,200)\end{array}$ & 3.75 & 5.32 & 5.88 & 7.06 & 6.60 & $\begin{array}{l}1.10\left(\mathrm{CH}_{3}\right) \\
2.25\left(\mathrm{CH}_{2}\right)\end{array}$ & 424 \\
\hline 6c & $\mathbf{H}$ & 27 & 170 & $\begin{array}{l}223(17,400) \\
286(19,700)\end{array}$ & 3.76 & 5.33 & 5.90 & 7.07 & 6.75 & $\begin{array}{l}5.33(=\mathrm{CH}) \text {, } \\
5.50(=\mathrm{CH})\end{array}$ & 396 \\
\hline
\end{tabular}

量

a Determined in $\mathrm{pH} 7$ phosphate buffer.

b $\mathrm{ABq}, J=18 \mathrm{~Hz}$ for $6 \mathrm{a}$ and $6 \mathrm{~b} ; \mathrm{s}$ for $7 \mathrm{a}, 7 \mathrm{~b}$ and $6 \mathrm{c}$.

d, $J=4.5 \mathrm{~Hz}$.

व $\mathbf{s}$

- d, $J=12 \mathrm{~Hz}$ for $6 \mathrm{a}$ and $6 \mathrm{~b} ; \mathrm{d}, J=16 \mathrm{~Hz}$ for $7 \mathrm{a}$ and $7 \mathrm{~b} ; \mathrm{dd}, J=12$ and $18 \mathrm{~Hz}$ for $6 \mathrm{c}$. 
gave the 3-butenyl (4b) and 3-vinyl (4c) ${ }^{13)}$ derivatives, respectively. The HPLC study indicated that $4 \mathrm{~b}$ contained $11 \%$ of its trans isomer. The $7-\mathrm{N}$-acylation of $\mathbf{4 b}$ followed by deblocking afforded the cis isomer $6 \mathrm{~b}(23 \%)$ and the trans isomer $7 \mathrm{~b}(3 \%)$ after chromatographic separation. The vinyl derivative $6 c^{14,15)}$ was also prepared similarly from $4 c$. The chemical data of 6 and 7 are shown in Table 1.

As can be seen in the table, distinct differences between $Z$ and $E$ isomers on the 3-alkenyl moiety were observed in their UV and ${ }^{1} \mathrm{H}$ NMR spectra. $Z$ isomers (6a and $6 \mathrm{~b}$ ) had an absorption maximum at near $280 \mathrm{~nm}$, whereas $E$ isomers ( $7 \mathbf{a}$ and $7 \mathbf{b}$ ) showed the maximum at $290 \mathrm{~nm}$ with greater intensity. The vinyl derivative $6 \mathrm{c}$ was similar to the $E$ isomers. The ${ }^{1} \mathrm{H}$ NMR of $Z$ isomers showed a doublet at ca. $6 \mathrm{ppm}(J=12 \mathrm{~Hz})$ assigned to a vinyl proton closer to the cephem nucleus $\left(\mathrm{H}_{\mathrm{b}}\right.$ in Table 1$)$ and an $\mathrm{AB}$ quartet at $c a .3 .6 \mathrm{ppm}$ due to the 2-H protons, whereas that of $E$ isomers resonated at lower field (ca. $6.6 \mathrm{ppm})$ with larger coupling constant $(J=16 \mathrm{~Hz})$ for the $\mathrm{H}_{\mathrm{b}}$ proton and at $c a .3 .7 \mathrm{ppm}$ as a two-proton singlet for the $2-\mathrm{H}$ protons. The ${ }^{1} \mathrm{H}$ NMR of $6 \mathrm{c}$ was also similar to that of the $E$ isomers for signals of the $\mathrm{H}_{\mathrm{b}}$ and 2-H protons. A similar observation has been previously reported on BMY28100 derivatives having 3-alkenyl side chains ${ }^{\theta}$.

The $O$-substituted analogs of the oxyimino moiety were prepared by the $N$-acylation of 4 a with appropriate $O$-substituted aminothiazolyl acids $\left(\mathbf{8 a} \sim \mathbf{8 d}^{12)}\right.$ and $\left.\mathbf{8 e}^{16)}\right)$ followed by deblocking as shown in Scheme 2. Only the predominant cis isomers (10) were isolated by chromatographic separation from the reaction mixture of the final products. The physico-chemical data of $\mathbf{1 0}$ are shown in Table 2.

BMY-28232 (6a) was esterified with 1-acetoxyethylbromide ${ }^{17)}$ in $N, N$-dimethylformamide in the

Scheme 2. Synthesis of $O$-substituted cephalosporins (10).
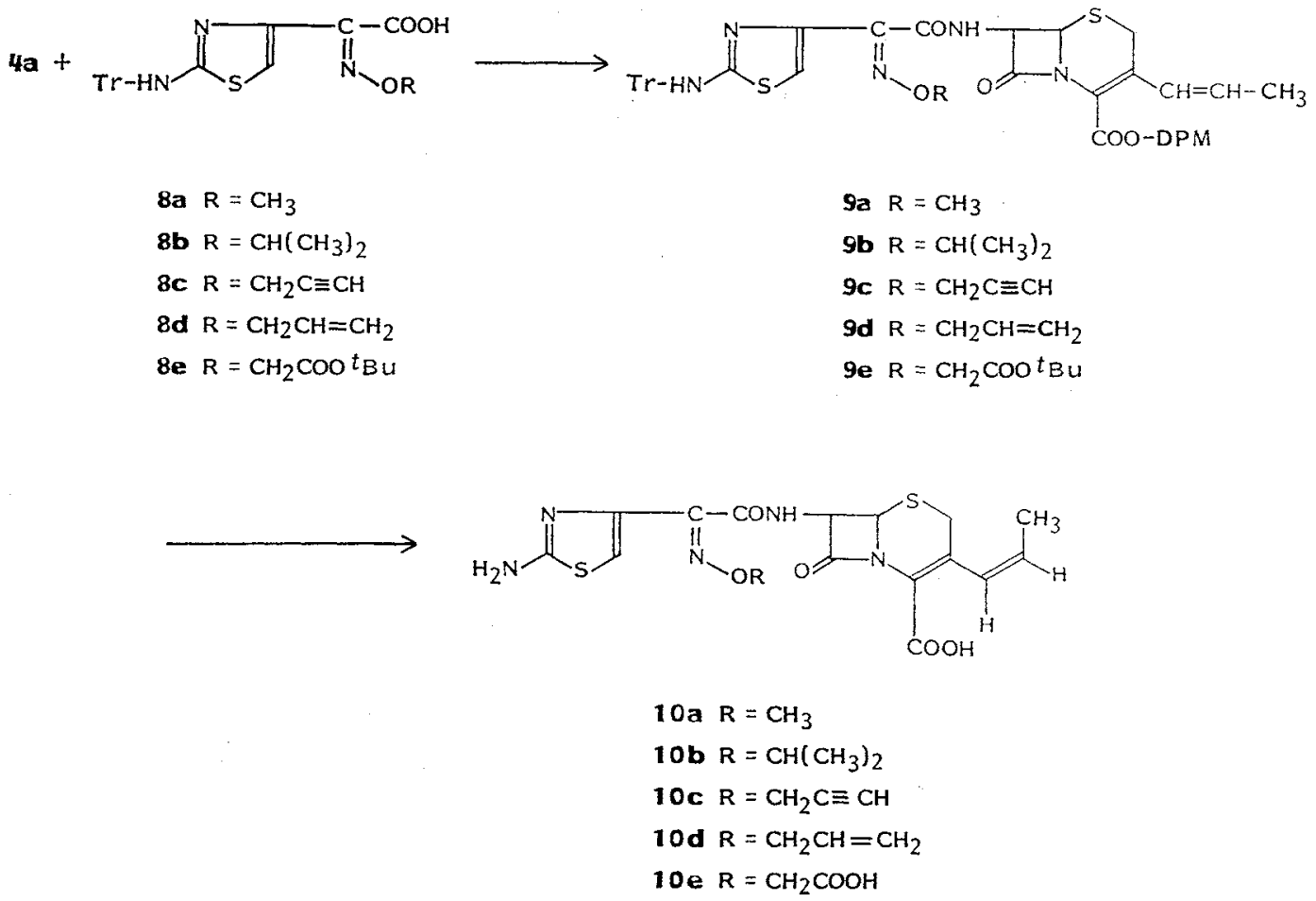

Tr: $\mathrm{C}\left(\mathrm{C}_{6} \mathrm{H}_{5}\right)_{3}$

DPM: $\mathrm{CH}\left(\mathrm{C}_{6} \mathrm{H}_{5}\right)_{2}$ 
Table 2. Yields, mp, UV, ${ }^{1} \mathrm{H}$ NMR and mass data of $O$-substituted cephalosporins (10).

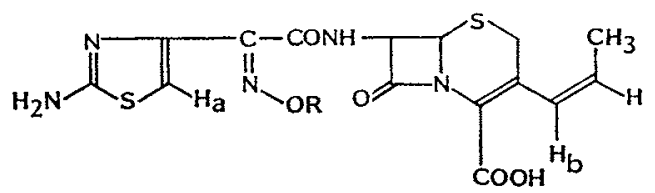

\begin{tabular}{|c|c|c|c|c|c|c|c|c|c|c|c|c|}
\hline \multirow{2}{*}{$\begin{array}{l}\text { Com- } \\
\text { pound }\end{array}$} & \multirow{2}{*}{$\mathbf{R}$} & \multirow{2}{*}{$\begin{array}{l}\text { Yield } \\
(\%)\end{array}$} & \multirow{2}{*}{$\begin{array}{c}\text { MP } \\
\left({ }^{\circ} \mathrm{C}, \mathrm{dec}\right)\end{array}$} & \multirow{2}{*}{$\mathrm{UV} \lambda_{\max } \mathrm{nm}(\varepsilon)^{\mathrm{a}}$} & \multicolumn{7}{|c|}{${ }^{1} \mathrm{H} \mathrm{NMR}\left(80 \mathrm{MHz}, \delta\right.$ in $\left.\mathrm{D}_{2} \mathrm{O}\left(+\mathrm{NaHCO}_{3}\right)\right)$} & \multirow{2}{*}{$\begin{array}{c}\text { Mass } \\
(m / z) \\
(\mathrm{M}+1)^{+} \\
\end{array}$} \\
\hline & & & & & $2-\mathrm{H}^{\mathrm{b}}$ & $6-\mathrm{H}^{\mathrm{c}}$ & $7-\mathrm{H}^{\mathrm{c}}$ & $\mathrm{H}_{\mathbb{8}}{ }^{\mathrm{d}}$ & $\mathrm{H}_{\mathrm{b}}{ }^{\theta}$ & $=\mathrm{CCH}_{3}{ }^{\mathrm{P}}$ & $\mathbf{R}$ & \\
\hline 10a & $\mathrm{CH}_{3}$ & 35 & 180 & $\begin{array}{l}232(16,400), \\
283(15,500)\end{array}$ & 3.62 & 5.35 & 5.90 & 7.15 & 6.10 & 1.75 & $4.13\left(\mathrm{CH}_{3}\right)$ & 424 \\
\hline 10b & $\mathrm{CH}\left(\mathrm{CH}_{3}\right)_{2}$ & 33 & $170 \sim 175$ & $\begin{array}{l}232(16,700) \\
284(16,200)\end{array}$ & 3.67 & 5.42 & 5.95 & 7.15 & 6.12 & 1.82 & $1.48\left(\mathrm{CH}_{3} \times 2\right)$ & 452 \\
\hline 10c & $\mathrm{CH}_{2} \mathrm{C} \equiv \mathrm{CH}$ & 22 & 155 & $\begin{array}{l}229(17,000) \\
285(14,500)\end{array}$ & 3.62 & 5.38 & 5.92 & 7.21 & 6.08 & 1.75 & $4.98\left(\mathrm{CH}_{2}\right)$ & 448 \\
\hline 10d & $\mathrm{CH}_{2} \mathrm{CH}=\mathrm{CH}_{2}$ & 50 & 140 & $\begin{array}{l}232(17,000) \\
285(14,700)\end{array}$ & 3.63 & 5.40 & 5.92 & 7.17 & 6.12 & 1.77 & $\mathrm{~g}$ & 450 \\
\hline $10 e$ & $\mathrm{CH}_{2} \mathrm{COOH}$ & 39 & 170 & $\begin{array}{l}235(14,800) \\
283(12,700)\end{array}$ & 3.58 & 5.35 & 5.92 & 7.15 & 6.05 & 1.75 & $4.68\left(\mathrm{CH}_{2}\right)$ & 468 \\
\hline
\end{tabular}

Determined in $\mathrm{pH} 7$ phosphate buffer.

b $\mathrm{ABq}, J=18 \mathrm{~Hz}$.

- d, $J=4.5 \mathrm{~Hz}$.

d $\mathrm{s.}$

- d, $J=12 \mathrm{~Hz}$

f $\mathrm{d}, J=6 \mathrm{~Hz}$.

g The $\mathrm{OCH}_{2}$ peak was overlapped with $\mathrm{DOH}$ signal. 
Fig. 2. BMY-28271 and related prodrug esters.<smiles>[R]OC(=O)/C=C\C(=O)N1CC(NC(=O)/C(=N/O)c2csc(N)n2)C1=O</smiles>

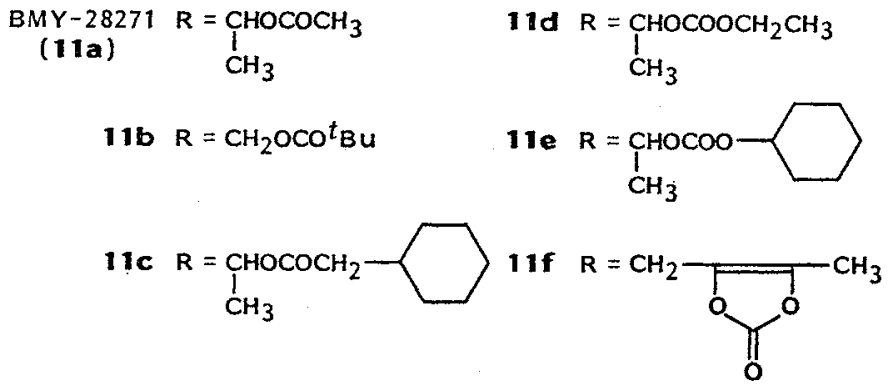

presence of $\mathrm{Na}_{2} \mathrm{CO}_{3}$. After chromatography on a silica gel column the 1-acetoxyethyl ester (BMY28271,11 ) was obtained in $24 \%$ yield as an amorphous powder, which was crystallized from EtOAc. In a similar way, reaction of $\mathbf{6 a}$ with pivaloyloxymethyl iodide, 1-cyclohexylacetyloxyethyl iodide ${ }^{7}$, 1-ethoxycarbonyloxyethyl iodide, 1-cyclohexyloxycarbonyloxyethyl iodide ${ }^{8)}$ and (5-methyl-2-oxo-1,3dioxolen-4-yl)methyl bromide ${ }^{18)}$ gave the corresponding esters (11b 11f) in 13 50\% yield (Fig. 2). The physico-chemical data of $\mathbf{1 1}$ are shown in Table 3. As shown in the last column of Table $\mathbf{3}$, the HPLC study revealed that 11a, 11c, 11d and 11e were a mixture of diastereoisomers regarding the asymetric carbon of the ester moiety and the ratio was almost $1: 1$. This was also supported by 400 $\mathrm{MHz}{ }^{1} \mathrm{H}$ NMR spectrum of 11a, in which most protons appeared as a pair of signals with almost the same intensity (see Experimental part), although the presence of a pair of signals was obscure in the spectrum determined by an $80 \mathrm{MHz}$ spectrometer.

\section{Biological Evaluation}

MICs of cephalosporin acids (6, 7 and 10) against 25 test organisms were determined by 2 -fold serial agar dilution method in Mueller-Hinton agar. The test organisms consist of five strains each of five groups which are described in Table 4. The in vitro activity of the test compounds was assessed by the geometric mean of MICs for each group of the test organisms.

The in vitro activity of BMY-28232 (6a), its 3-modified analogs (6 and 7) and the $O$-substituted derivatives (10) are shown in Table 5. The 3- $Z$-propenyl derivative (BMY-28232, 6a) was the most active among the cephalosporins tested in the present series. The 3-Z-butenyl (6b) and 3-vinyl (6c) derivatives were as active as $\mathbf{6 a}$ against Gram-positive species (Gp-Ia and $\mathrm{Gp}-\mathrm{Ib}$ ), but less active than 6a against Gram-negative groups (Gn-Ia, $-\mathrm{Ib}$ and $-\mathrm{II}$ ). The $E$-propenyl (7a) and $E$-butenyl (7b) derivatives were similar to their $Z$ isomers ( $6 \mathbf{a}$ and $\mathbf{6 b}$ ) in Gram-positive activity, but much less active than the latters against Gram-negative species.

Generally $O$-substitution of the hydroxyimino moiety of 6 a resulted in reducing the Gram-positive activity. Thus, the methoxyimino derivative (10a) was nearly as active as $\mathbf{6 a}$ against Gram-negative species, but significantly less active against both Gram-positive groups (Gp-Ia and Gp-Ib). The $O$-allyl derivative (10d) showed fairly good Gram-positive activity, but decreased Gram-negative 
Table 3. Yields, mp, UV, ${ }^{1} \mathrm{H}$ NMR, HPLC and mass data of BMY-28271 and related compounds (11).

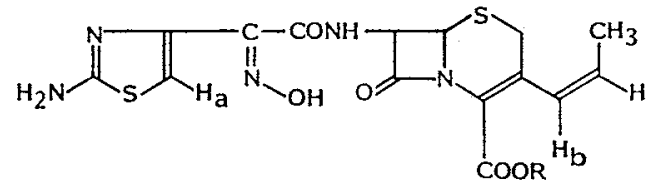

\begin{tabular}{|c|c|c|c|c|c|c|c|c|c|c|c|}
\hline \multirow{2}{*}{ Compound } & \multirow{2}{*}{$\mathbf{R}$} & \multirow{2}{*}{$\begin{array}{l}\text { Yield } \\
(\%)\end{array}$} & \multirow{2}{*}{$\begin{array}{c}\mathrm{MP} \\
\left({ }^{\circ} \mathrm{C}, \mathrm{dec}\right)\end{array}$} & \multirow{2}{*}{$\begin{array}{c}\mathrm{UV} \lambda_{\max }^{\mathrm{E}+\mathrm{EH}} \\
\mathrm{nm}(\varepsilon)\end{array}$} & \multicolumn{5}{|c|}{${ }^{1} \mathrm{H} \mathrm{NMR}\left(80 \mathrm{MHz}, \delta\right.$ in $\left.\mathrm{CDCl}_{3}\right)$} & \multirow{2}{*}{$\begin{array}{l}\text { HPLC }^{\circ} \\
\text { room temp } \\
\text { (minutes) }\end{array}$} & \multirow{2}{*}{$\begin{array}{c}\text { Mass } \\
(m / z) \\
(\mathrm{M}+1)^{+}\end{array}$} \\
\hline & & & & & $2-\mathrm{H}^{\mathrm{a}}$ & $6-\mathrm{H}^{\mathrm{b}}$ & $\mathrm{H}_{\mathrm{a}}{ }^{\mathrm{c}}$ & $\mathbf{H}_{b}{ }^{d}$ & Ester moiety & & \\
\hline $\begin{array}{c}11 a \\
(B M Y-28271)\end{array}$ & $\begin{array}{l}\mathrm{CHOCOCH} \\
\mathrm{CH}_{3}\end{array}$ & 24 & $146 \sim 149$ & $\begin{array}{l}223(19,000), \\
286(12,000)\end{array}$ & 3.45 & 5.10 & 7.04 & 6.15 & $\begin{array}{l}1.52(3 \mathrm{H}, \mathrm{d}) \\
2.10(3 \mathrm{H}, \mathrm{s})\end{array}$ & $8.6,8.9$ & 496 \\
\hline $11 b$ & $\mathrm{CH}_{2} \mathrm{OCO}$-tert-Bu & 50 & $115 \sim 120$ & $\begin{array}{l}222(19,000), \\
285(12,000)\end{array}$ & 3.45 & 5.10 & 7.00 & 6.15 & $\begin{array}{l}1.25(9 \mathrm{H}, \mathrm{s}) \\
5.85(2 \mathrm{H}, \mathrm{ABq})\end{array}$ & 8.0 & 524 \\
\hline 11c & $\underset{\stackrel{\mathrm{C}}{\mathrm{C}} \mathrm{H}_{3}}{\mathrm{CHOCO}}$ & 13 & $115 \sim 120$ & $\begin{array}{l}224(18,000), \\
285(11,300)\end{array}$ & 3.45 & 5.08 & 7.00 & 6.15 & $\begin{array}{l}1.52(3 \mathrm{H}, \mathrm{d}) \\
0.90 \sim 1.90 \\
(11 \mathrm{H}, \mathrm{m})\end{array}$ & $9.1,9.6$ & 578 \\
\hline 11d & $\begin{array}{l}\mathrm{CHOCOOC}_{2} \mathrm{H}_{5} \\
\mathrm{CH}_{3}\end{array}$ & 17 & $105 \sim 110$ & $\begin{array}{l}222(20,000), \\
286(11,000)\end{array}$ & 3.47 & 5.10 & 7.03 & 6.17 & $\begin{array}{l}1.36(3 \mathrm{H}, \mathrm{t}), \\
1.55(3 \mathrm{H}, \mathrm{d}), \\
4.23(2 \mathrm{H}, \mathrm{q})\end{array}$ & $12.9,14.1$ & 526 \\
\hline 11e & $\underset{\substack{\mathrm{CHOCOO} \\
\mathrm{CH}_{3}}}{\mathrm{CHOCO}-}$ & 28 & $115 \sim 120$ & $\begin{array}{l}224(20,000) \\
284(12,000)\end{array}$ & 3.44 & 5.07 & 7.00 & 6.15 & $\begin{array}{l}1.55(3 \mathrm{H}, \mathrm{d}) \\
0.8 \sim 2.0 \\
(10 \mathrm{H}, \mathrm{m})\end{array}$ & $9.5,10.7$ & 580 \\
\hline $11 f$ & $-\mathrm{CH}_{2} \underset{\mathrm{O}}{\mathrm{O}_{3}}$ & 39 & $115 \sim 120$ & $\begin{array}{l}225(19,000) \\
287(12,000)\end{array}$ & 3.45 & 5.11 & 7.00 & 6.13 & $\begin{array}{l}2.17(3 \mathrm{H}, \mathrm{s}) \\
4.96(2 \mathrm{H}, \mathrm{s})\end{array}$ & 4.9 & 522 \\
\hline
\end{tabular}

a br s.

b d, $J=5.5 \mathrm{~Hz}$.

c s.

d d, $J=12 \mathrm{~Hz}$.

- Column: SSC-ODS-262, $6 \times 100 \mathrm{~mm}$ (Senshu Pak), detection: UV at $254 \mathrm{~nm}$, flow rate: $1 \mathrm{ml} / \mathrm{minute}$, mobile phase: $\mathrm{CH}_{3} \mathrm{CN}-\mathrm{pH} 2.6 \mathrm{buffer}(11 \mathrm{a}, 30: 70 ; 11 \mathrm{~b}$, $45: 55$; 11c, $50: 50$; 11d, $35: 65$; 11e, $45: 55$; 11f, $40: 60$ ). 
Table 4. Test organisms for the primary evaluation of cephalosporins.

\begin{tabular}{clc}
\hline Group & \multicolumn{1}{c}{ Organism } & $\begin{array}{c}\text { Number of } \\
\text { strains }\end{array}$ \\
\hline Gp-Ia & Penicillinase (Pen-ase)-negative Staphylococcus aureus & 5 \\
Gp-Ib & Pen-ase-positive S. aureus & 5 \\
Gn-Ia & Cephalothin (CET)-sensitive Escherichia coli (2 strains), Klebsiella & 5 \\
& pneumoniae (1) and Proteus mirabilis (2) & \\
Gn-Ib & CET-resistant E. coli (3) and K. pnetumoniae (2) & 5 \\
Gn-II & $\begin{array}{l}\text { Morganella morganii (1), Enterobacter cloacae (2) and Serratia marcescens } \\
\end{array}$ & 5 \\
\hline
\end{tabular}

Table 5. In vitro activity of BMY-28232 and analogs (Mueller-Hinton agar, $10^{6} \mathrm{cfu} / \mathrm{ml}, 37^{\circ} \mathrm{C}, 18$ hours).

\begin{tabular}{cccccc}
\hline \multirow{2}{*}{ Compound } & \multicolumn{5}{c}{ Geometric mean of MIC $(\mu \mathrm{g} / \mathrm{ml})$} \\
\cline { 2 - 6 } & Gp-Ia ${ }^{\mathrm{a}}$ & Gp-Ib & Gn-Ia & Gn-Ib & Gn-II \\
\hline 6a & 0.23 & 0.40 & 0.076 & 0.35 & 5.5 \\
$($ BMY-28232) & & & & & \\
$\mathbf{6 b}$ & 0.26 & 0.40 & 0.20 & 0.79 & 7.3 \\
$\mathbf{6 c}$ & 0.30 & 0.53 & 0.17 & 0.91 & 14 \\
$\mathbf{7 a}$ & 0.23 & 0.61 & 0.46 & 2.1 & 33 \\
$\mathbf{7 b}$ & 0.23 & 0.61 & 0.69 & 3.2 & 22 \\
$\mathbf{1 0 a}$ & 1.8 & 3.6 & 0.10 & 0.52 & 6.3 \\
$\mathbf{1 0 b}$ & 1.6 & 2.7 & 0.53 & 1.2 & 8.3 \\
$\mathbf{1 0 c}$ & 1.4 & 1.6 & 0.23 & 0.91 & 14 \\
$\mathbf{1 0 d}$ & 0.46 & 0.80 & 0.70 & 2.1 & 29 \\
$\mathbf{1 0 e}$ & 14 & 29 & 0.029 & 0.30 & 4.2 \\
Cefuroxime & 0.92 & 1.8 & 1.4 & 6.3 & 44 \\
Cefaclor & 0.92 & 4.7 & 1.1 & 7.2 & $>100$ \\
\hline
\end{tabular}

a See Table 4.

activity. On the contrary the $O$-carboxymethyl derivative (10e) was more active than 6 a and $10 a$ against Gram-negative groups, but showed only very weak Gram-positive activity.

In view of the above results, BMY-28232 (6a) was selected as a lead compound in this series and evaluated further for its in vitro activity, absorption and in vivo efficacy following intramuscular and oral administrations to mice. Table 6 shows the in vitro activity of 6 a compared with that of cefuroxime against standard strains of bacteria stocked in our laboratory. This confirmed the results of the primary assessment described above. As shown in Table 7, 6a was well absorbed by intramuscular injection to mice, and was effective in vivo against infections produced by Staphylococcus aureus Smith and Escherichia coli Juhl. However 6a showed limited absorption by an oral administration and its oral in vivo activity was less than one fifth that obtained by im route against $S$. aureus and $E$. coli infections. Modification of $6 \mathbf{a}$ to its prodrug-type esters $(11 \mathrm{a} \sim 11 \mathrm{f})$ resulted in a singificant improvement of its oral absorption. The pharmacokinetic parameters and in vivo activities against $S$. aureus Smith and $E$. coli Juhl of the prodrug esters were compared with those of cefuroxime axetil and cefaclor after an oral administration to mice. The results are summarized in Table 8. The relative oral bioavailability of the esters calculated from the oral AUC value of a prodrug and the AUC value of the parent acid (6a) administered intravenously at equivalent dose. This series of esters, with an exception of 11f, showed higher oral bioavailabilities $(60 \sim 66 \%)$ than those of cefuroxime axetil $(46 \%)$ and cefaclor $(51 \%)$. 
Table 6. Antibacterial spectrum of $6 a$ and cefuroxime against standard strains of bacteria.

\begin{tabular}{|c|c|c|}
\hline \multirow{2}{*}{ Test organism } & \multicolumn{2}{|c|}{$\operatorname{MIC}(\mu \mathrm{g} / \mathrm{ml})$} \\
\hline & $6 a$ & Cefuroxime \\
\hline Staphylococcus aureus FDA $209 \mathrm{P}$ JC-1 & 0.4 & 1.6 \\
\hline S. aureus Smith & 0.4 & 1.6 \\
\hline S. aureus Terajima & 0.4 & 0.8 \\
\hline S. aureus MS 353 & 0.2 & 0.8 \\
\hline Escherichia coli NIHJ JC-2 & 0.2 & 6.3 \\
\hline E. coli $\mathrm{K}-12 \mathrm{C} 600$ & 0.4 & 6.3 \\
\hline Klebsiella pneumoniae PCI-602 & 0.025 & 0.05 \\
\hline Salmonella typhimurium IID 971 & 0.4 & 12.5 \\
\hline S. typhi 901 & 0.1 & 3.1 \\
\hline S. paratyphi 1015 & 0.1 & 0.2 \\
\hline S. schottmuelleri 8006 & 0.05 & 0.1 \\
\hline S. enteritidis G 14 & 0.1 & 3.1 \\
\hline Proteus mirabilis IFO 3849 & 0.4 & 3.1 \\
\hline P. vulgaris OX 19 & 0.2 & 3.1 \\
\hline P. vulgaris $\mathrm{HX} 19$ & 0.1 & 0.8 \\
\hline Providencia rettgeri IFO 3850 & $<0.006$ & 0.1 \\
\hline Morganella morganii IFO 3848 & 0.4 & 0.8 \\
\hline Enterobacter aerogenes ATCC 13048 & 0.8 & 6.3 \\
\hline E. cloacae 963 & 1.6 & 6.3 \\
\hline Serratia marcescens IAM 1184 & 0.8 & 50 \\
\hline Pseudomonas aeruginosa IFO 3445 & $>50$ & $>50$ \\
\hline$P$. aeruginosa NCTC 10490 & 25 & 50 \\
\hline$P$. aeruginosa $\mathrm{PAO} 1$ & $>50$ & $>50$ \\
\hline
\end{tabular}

Table 7. Blood level and $\mathrm{PD}_{50}$ of $6 \mathrm{a}(\mathrm{BMY}-28232)$ by im, iv, and oral administrations in mice $(n=10)$.

\begin{tabular}{|c|c|c|c|c|c|c|}
\hline \multirow{2}{*}{ Route } & \multicolumn{4}{|c|}{ Blood level } & \multicolumn{2}{|c|}{$\mathrm{PD}_{50}(\mathrm{mg} / \mathrm{kg})$} \\
\hline & $\underset{(\mathrm{mg} / \mathrm{kg})}{\text { Dose }}$ & $\frac{\mathrm{C}_{\max }}{(\mu \mathrm{g} / \mathrm{ml})}$ & $\begin{array}{c}\mathrm{T}_{1 / 2} \\
\text { (hours) }\end{array}$ & $\begin{array}{c}\text { AUC } \\
(\mu \mathrm{g} \cdot \text { hours } / \mathrm{ml})\end{array}$ & S.a. & E.c. \\
\hline $\mathrm{im}$ & 100 & 86 & 0.74 & 126 & 0.26 & 0.23 \\
\hline iv & 100 & 516 & 0.51 & 117 & & \\
\hline Oral & 100 & 6.9 & 2.2 & 23 & 2.3 & 1.4 \\
\hline
\end{tabular}

S.a., Staphylococcus aureus Smith; E.c., Escherichia coli Juh1.

The prodrug esters in the present study $(11 a \sim 11)$ were all more effective than cefuroxime axetil against $S$. aureus and $E$. coli infections. BMY-28271 (11a) appeared to be the most effective compound against both infections and also more active than cefaclor. Other esters $(\mathbf{1 1 b} \sim \mathbf{1 1 f})$ appeared more active than cefaclor against $E$. coli Juhl, although somewhat less active against $S$. aureus Smith.

Further evaluation on BMY-28232 and selected prodrug esters will be described in a separate paper.

\section{Experimental}

MP's were determined using a Yanagimoto micro hot-stage apparatus and are uncorrected. IR spectra were recorded on a Jasco IRA-1 spectrometer and UV spectra on a Shimadzu UV-200 spectrophotometer. NMR spectra were recorded on Varian FT-80A (80 MHz) and Jeol GX-400 (400 $\mathrm{MHz}$ ). Mass spectra were recorded on a Hitachi M-80 mass spectrometer (secondary ion (SI)-MS). 
Table 8. Blood level and $\mathrm{PD}_{50}$ of BMY-28271 and analogs (11) after oral administration to mice $(n=5)$.

\begin{tabular}{|c|c|c|c|c|c|c|c|}
\hline \multirow[b]{2}{*}{ Compound } & \multirow[b]{2}{*}{$\mathbf{R}$} & \multicolumn{3}{|c|}{ Blood level (dose $=100 \mathrm{mg} / \mathrm{kg}$ ) } & \multirow[b]{2}{*}{$\underset{(\%)}{\text { B.A.** }}$} & \multicolumn{2}{|c|}{$\mathrm{PD}_{50}(\mathrm{mg} / \mathrm{kg})$} \\
\hline & & $\underset{(\mu \mathrm{g} / \mathrm{ml})}{\mathrm{C}_{\max }}$ & $\begin{array}{c}\mathrm{T}_{1 / 2} \\
\text { (hours) }\end{array}$ & $\begin{array}{c}\text { AUC } \\
(\mu \mathrm{g} \cdot \\
\text { hours } / \mathrm{ml})\end{array}$ & & S.a. & E.c. \\
\hline $\begin{array}{c}11 \mathrm{a} \\
(\mathrm{BMY}-28271)\end{array}$ & $\begin{array}{l}\mathrm{CHOCOCH} \\
\stackrel{1}{\mathrm{CH}_{3}}\end{array}$ & 41 & 1.7 & 77 & 66 & 0.68 & 0.54 \\
\hline $11 b$ & $\mathrm{CH}_{2} \mathrm{OCO}-t e r t-\mathrm{Bu}$ & 34 & 2.2 & 71 & 61 & 0.99 & 0.70 \\
\hline $11 \mathrm{c}$ & $\begin{array}{c}-\mathrm{CHOCOCH}_{1}^{+} \\
\mathrm{CH}_{3}\end{array}$ & 33 & 2.3 & 70 & 60 & 2.7 & 1.4 \\
\hline $11 d$ & $\begin{array}{l}\mathrm{CHOCOOCH}_{2} \mathrm{CH}_{3} \\
\stackrel{\mathrm{C}}{\mathrm{C}} \mathrm{H}_{3}\end{array}$ & 32 & 2.9 & 74 & 63 & 1.4 & 1.1 \\
\hline $11 \mathrm{e}$ & $\begin{array}{c}-\mathrm{CHOCO} \\
\stackrel{\mathrm{C}}{\mathrm{CH}} \mathrm{H}_{3}\end{array}$ & 48 & 2.0 & 77 & 66 & 1.0 & 1.2 \\
\hline $11 f$ & $-\mathrm{CH}_{2} \rightleftharpoons \mathrm{CH}_{3}$ & 16 & 2.3 & 44 & 38 & 2.0 & 1.2 \\
\hline Cefuroxime axe & & 27 & 1.5 & 36 & 46 & 6.1 & 8.8 \\
\hline Cefaclor & & 32 & 1.0 & 41 & 51 & 0.81 & 1.8 \\
\hline
\end{tabular}

* Relative bioavailability: 11a $\sim 11$, [AUC(po) of the prodrugs (11)/AUC(iv) of (6a)] $\times 100$; cefuroxime axetil, [AUC(po) of cefuroxime axetil/AUC(iv) of cefuroxime] $\times 100$; cefaclor, $[A U C(\mathrm{po})$ of cefaclor/ AUC(iv) of cefaclor $\times 100$.

S.a., Staphylococcus aureus Smith; E.c., Escherichia coli Juhl.

Diphenylmethyl 7-Benzylideneamino-3-[(triphenylphosphoranylidene)methyl]-3-cephem-4-carboxylate (2)

Diphenylmethyl 7-benzylideneamino-3-chloromethyl-3-cephem-4-carboxylate (1, $48.4 \mathrm{~g}, 96.2 \mathrm{mmol})$ was added to a stirred solution of $\mathrm{PPh}_{3}(25.2 \mathrm{~g}, 96.2 \mathrm{mmol})$ in $\mathrm{CH}_{2} \mathrm{Cl}_{2}(50 \mathrm{ml})$ at room temperature under nitrogen atmosphere. The resulting pale yellow solution was continued to be stirred for 4 days at room temperature. The viscous reaction mixture was diluted with $\mathrm{CH}_{2} \mathrm{Cl}_{2}(300 \mathrm{ml})$, and an aqueous solution of $5 \mathrm{~N} \mathrm{Na}_{2} \mathrm{CO}_{3}(100 \mathrm{ml}, 5$ equiv) was added in one portion under vigorous stirring. The mixture being stirred for 50 minutes was separated and the aqueous layer was extracted with $\mathrm{CH}_{2} \mathrm{Cl}_{2}(3 \times 70 \mathrm{ml})$. The combined organic extracts were dried over anhydrous $\mathrm{MgSO}_{4}$ and filtered. The dark red filtrate was concentrated in vacuo to a volume of about $150 \mathrm{ml}$. The concentrate was poured into acetone $(400 \mathrm{ml})$ with stirring and the resulting solid was collected by filtration and washed with acetone $(300 \mathrm{ml})$. The solid was then dried under reduced pressure at room temperature in the dark. Yield $56.7 \mathrm{~g}(81 \%)$ : UV $\lambda_{\mathrm{max}}^{\mathrm{CH}_{2} \mathrm{Cl}_{2}} \mathrm{~nm}(\varepsilon) 255(24,900), 388(24,300) ; \mathrm{mp} 219 \sim 220^{\circ} \mathrm{C}(\mathrm{dec})$.

Anal Calcd for $\mathrm{C}_{48} \mathrm{H}_{37} \mathrm{~N}_{2} \mathrm{O}_{3} \mathrm{PS}$ : C 75.81, H 5.12, N 3.84, $\mathrm{S} 4.40$.

Found:

C 75.39, H 5.16, N 3.82, S 4.71.

The Wittig Reaction Products: Diphenylmethyl 7-Amino-3-(1-propenyl)-3-cephem-4-carboxylate Hydrochloride (4a)

To a chilled solution of lithium bromide $(43.4 \mathrm{~g}, 0.5 \mathrm{~mol})$ in DMF $(200 \mathrm{ml})$ and $\mathrm{CH}_{2} \mathrm{Cl}_{2}(200 \mathrm{ml})$ was added a solution of the ylide $2(36.5 \mathrm{~g}, 0.05 \mathrm{~mol})$ in $\mathrm{CH}_{2} \mathrm{Cl}_{2}(200 \mathrm{ml})$. To the mixture was added acetaldehyde $(50 \mathrm{ml})$ under stirring. The mixture was allowed to stand for 24 hours at room temperature and concentrated under reduced pressure. The residue was diluted with EtOAc (1.5 liters), washed with water, dried over anhydrous $\mathrm{MgSO}_{4}$ and filtered. To the filtrate was added Silica gel (Wakogel C-100, 50 g). The mixture was filtered and the filtrate was concentrated to $c a .500 \mathrm{ml}$. 
To the concentrate was added a solution of Girard T reagent $(25.2 \mathrm{~g}, 0.15 \mathrm{~mol})$ in $\mathrm{MeOH}(400 \mathrm{ml})$ and $\mathrm{AcOH}(20 \mathrm{ml})$ and the mixture was stirred for 20 minutes. After removal of $\mathrm{MeOH}$ under reduced pressure, the mixture was diluted with EtOAc (1 liter), washed with aq $\mathrm{NaHCO}_{3}$ and then water. The organic solution was dried and concentrated in vacuo. The concentrate was diluted with ether (1 liter) and then $1.5 \mathrm{~N} \mathrm{HCl}-\mathrm{MeOH}(25 \mathrm{ml})$ was added to precipitate the crude product $(\mathrm{ca} .20 \mathrm{~g})$, which was dissolved in a mixture of $\mathrm{MeOH}(100 \mathrm{ml})$ and EtOAc $(300 \mathrm{ml})$, and treated with a small amount of charcoal. The solution was filtered and the filtrate was concentrated in vacuo to afford a crystalline product, which was collected by filtration and dried. Yield $15.7 \mathrm{~g}(71 \%): \mathrm{MP} 165 \sim 170^{\circ} \mathrm{C}$; IR $\nu_{\max }^{\mathrm{KBr}}$ $\mathrm{cm}^{-1} 1782,1722$; UV $\lambda_{\max }^{\mathrm{EtOH}} \mathrm{nm}(\varepsilon) 285(7,600) ;{ }^{1} \mathrm{H}$ NMR $\left(80 \mathrm{MHz}, \mathrm{DMSO}-d_{8}\right) \delta 1.47(3 \mathrm{H}, \mathrm{dd}, J=2$ and $\left.7 \mathrm{~Hz}, \mathrm{CH}=\mathrm{CHCH}_{3}\right), 3.65(2 \mathrm{H}, \mathrm{ABq}, J=18 \mathrm{~Hz}, 2-\mathrm{H}), 5.15(1 \mathrm{H}, \mathrm{d}, J=5.5 \mathrm{~Hz}, 6-\mathrm{H}$ or $7-\mathrm{H}), 5.30$ $(1 \mathrm{H}, \mathrm{d}, J=5.5 \mathrm{~Hz}, 6-\mathrm{H}$ or $7-\mathrm{H}), 5.45 \sim 5.75\left(1 \mathrm{H}, \mathrm{m}, \mathrm{CH}=\mathrm{CHCH}_{3}\right), 6.23(1 \mathrm{H}, \mathrm{d}, J=12 \mathrm{~Hz}, \mathrm{CH}=$ $\left.\mathrm{CHCH}_{3}\right), 6.85\left(1 \mathrm{H}, \mathrm{s}, \mathrm{Ph}_{2} \mathrm{CH}\right), 7.1 \sim 7.5(10 \mathrm{H}, \mathrm{m}$, phenyl). HPLC study showed that this product contained about $15 \%$ of the $E$ isomer. HPLC (column Senshu Pak SSC-ODS-262, $254 \mathrm{~nm}$, solvent $70 \% \mathrm{MeOH}-\mathrm{pH} 7$ buffer, $2 \mathrm{ml} /$ minute): $Z$ isomer 5.7 minutes, $E$ isomer 7.1 minutes.

Anal Calcd for $\mathrm{C}_{23} \mathrm{H}_{22} \mathrm{~N}_{2} \mathrm{O}_{3} \mathrm{~S} \cdot \mathrm{HCl}$ : C 62.36, H 5.23, N 6.32, S 7.24, $\mathrm{Cl} 8.00$. Found:

C 62.29, H 5.18, N 6.10, S 7.24, Cl 7.92.

Diphenylmethyl 7-Amino-3-(1-butenyl)-3-cephem-4-carboxylate Hydrochloride (4b)

The Wittig reaction of $2(7.3 \mathrm{~g}, 10 \mathrm{mmol})$ using propionaldehyde instead of acetaldehyde gave $1.49 \mathrm{~g}(33 \%)$ of $4 \mathrm{~b}$ by a similar procedure to $4 \mathrm{a}: \mathrm{MP} 120 \sim 127^{\circ} \mathrm{C}$; IR $\nu_{\mathrm{max}}^{\mathrm{KBr}} \mathrm{cm}^{-1} 1780,1710$; UV $\lambda_{\max }^{\mathrm{EtOH}} \mathrm{nm}(\varepsilon) 286(7,400) ;{ }^{1} \mathrm{H} \mathrm{NMR}\left(80 \mathrm{MHz}, \mathrm{DMSO}-d_{6}\right) \delta 0.93\left(3 \mathrm{H}, \mathrm{t}, J=7 \mathrm{~Hz}, \mathrm{CH}_{2} \mathrm{CH}_{3}\right), 2.00(2 \mathrm{H}$, $\left.\mathrm{m}, \mathrm{CH}_{2} \mathrm{CH}_{3}\right), 3.75(2 \mathrm{H}, \mathrm{ABq}, J=18 \mathrm{~Hz}, 2-\mathrm{H}), 5.22(1 \mathrm{H}, \mathrm{d}, J=5.5 \mathrm{~Hz}, 6-\mathrm{H}$ or $7-\mathrm{H}), 5.40(1 \mathrm{H}, \mathrm{d}, J=$ $5.5 \mathrm{~Hz}, 6-\mathrm{H}$ or $7-\mathrm{H}), 6.33\left(1 \mathrm{H}, \mathrm{d}, J=12 \mathrm{~Hz}, \mathrm{CH}=\mathrm{CHCH}_{2}\right), 6.97\left(1 \mathrm{H}, \mathrm{s}, \mathrm{Ph}_{2} \mathrm{CH}\right), 7.40(10 \mathrm{H}, \mathrm{m}$, phenyl). HPLC study showed that this product contained $11 \%$ of the $E$ isomer. HPLC (column LiChrosorb RP-18 (25 cm $\times 4 \mathrm{~mm}$ i.d.), $254 \mathrm{~nm}$, solvent $60 \% \mathrm{CH}_{3} \mathrm{CN}-\mathrm{pH} 7$ buffer, $2 \mathrm{ml} /$ minute): $Z$ isomer 5.1 minutes, $E$ isomer 6.7 minutes.

Acylated Products (5): General Procedures Illustrated with the Preparation of 7-[( $Z$ )-2-(2-Tritylaminothiazol-4-yl)-2-trityloxyiminoacetamido]-3-(1-propenyl)-3-cephem-4-carboxylate (5a)

To a chilled mixture of $(Z)$-2-(2-tritylaminothiazol-4-yl)-2-trityloxyiminoacetic acid $(7.27 \mathrm{~g}$, $10.8 \mathrm{mmol})$ and 1-hydroxybenzotriazole hydrate $(1.65 \mathrm{~g}, 10.8 \mathrm{mmol})$ in dry THF $(180 \mathrm{ml})$ was added dicyclohexylcarbodiimide (DCC) $(2.23 \mathrm{~g}, 10.8 \mathrm{mmol})$ and the mixture was stirred for 1 hour at $5^{\circ} \mathrm{C}$ and filtered to afford the active ester solution. A suspension of $4 \mathrm{a}(3.99 \mathrm{~g}, 9 \mathrm{mmol})$ in EtOAc $(50 \mathrm{ml})$ was washed with aq $\mathrm{NaHCO}_{3}$ and water, successively and evaporated under reduced pressure. The residue was dissolved in THF $(30 \mathrm{ml})$ and added into the above-prepared active ester solution. The mixture was stirred overnight at room temperature and concentrated under reduced pressure. The residue was dissolved in EtOAc, washed with water and concentrated under reduced pressure. The residue was chromatographed on a Silica gel column (Merck Kieselgel 60,90 g) and the column was eluted with a mixture of toluene and EtOAc $(20: 1)$ to give $9.4 \mathrm{~g}(98 \%)$ of $5 \mathrm{a}$ as an amorphous powder. SI-MS $m / z \quad 1,060(\mathrm{M}+1)^{+}$.

Compounds $\mathbf{5 b}$ and $\mathbf{5 c}$ were prepared by a similar procedure in $87 \%$ and $95 \%$ yield, respectively. Data of 5 are summarized in Table 9.

3-Z- and E-Alkenyl Cephalosporins (6 and 7): General Procedure Illustrated with the Preparation of 7-[(Z)-2-(2-Aminothiazol-4-yl)-2-hydroxyiminoacetamido]-3-[( $Z$ )- and (E)-1-propenyl]-3-cephem-4carboxylic Acids (6a and 7a)

A mixture of $5 \mathrm{a}(9.2 \mathrm{~g}, 8.7 \mathrm{mmol})$ in $85 \%$ formic acid $(30 \mathrm{ml})$ was stirred for 1 hour at room temperature. Hydrochloric acid $(1 \mathrm{ml})$ was added and the mixture was stirred for 2 hours. Evaporation of the mixture under reduced pressure followed by trituration of the residue with isopropyl ether gave the crude product, which was chromatographed on a column of $\mathrm{C}_{18}$ Silica gel (the packing of prepPAK$500 / \mathrm{C}_{18}$ (Waters), $300 \mathrm{ml}$ ). The column was eluted with water, $10 \% \mathrm{MeOH}$ and $20 \% \mathrm{MeOH}$, successively and the fractions were monitored by HPLC (column Senshu Pak SSC-ODS-262, solvent $\mathrm{CH}_{3} \mathrm{CN}-\mathrm{pH}$ 2.6 buffer (15:85), $1 \mathrm{ml} /$ minute, $Z$ isomer 5.6 minutes, $E$ isomer 7.8 minutes). The fractions contain- 
Table 9. Yields and ${ }^{1} \mathrm{H}$ NMR of the acylation products (5 and 9).

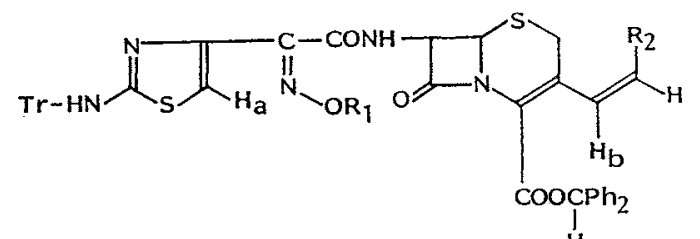

$\mathrm{H}_{\mathrm{C}}$

\begin{tabular}{|c|c|c|c|c|c|c|c|c|c|c|}
\hline \multirow{2}{*}{ Compound } & \multirow{2}{*}{$\mathbf{R}_{1}$} & \multirow{2}{*}{$\mathbf{R}_{2}$} & \multirow{2}{*}{$\begin{array}{l}\text { Yield } \\
(\%)\end{array}$} & \multicolumn{7}{|c|}{${ }^{1} \mathrm{H} \mathrm{NMR}\left(80 \mathrm{MHz}, \delta\right.$ in $\left.\mathrm{CDCl}_{3}\right)$} \\
\hline & & & & $2-\mathrm{H}^{\mathrm{a}}$ & $6-\mathrm{H}^{\mathrm{b}}$ & $\mathrm{H}_{\mathrm{a}}{ }^{\mathrm{e}}$ & $\mathrm{H}_{\mathrm{b}}{ }^{\mathrm{d}}$ & $\mathrm{H}_{\mathrm{c}}{ }^{\mathrm{e}}$ & $=\mathrm{CCH}_{3}{ }^{\mathrm{e}}$ & Others \\
\hline $\mathbf{5 a}$ & $\mathrm{C}\left(\mathrm{C}_{8} \mathrm{H}_{5}\right)_{3}$ & $\mathrm{CH}_{3}$ & 98 & 3.20 & 5.05 & 6.40 & 6.05 & 6.90 & 1.40 & -- \\
\hline $\mathbf{5 b}$ & $\mathrm{C}\left(\mathrm{C}_{6} \mathrm{H}_{5}\right)_{3}$ & $\mathrm{C}_{2} \mathrm{H}_{5}$ & 87 & 3.22 & 5.15 & 6.43 & 6.06 & 6.92 & - & $0.83\left(\mathrm{CCH}_{3}\right)$ \\
\hline $5 \mathbf{c}$ & $\mathrm{C}\left(\mathrm{C}_{6} \mathrm{H}_{5}\right)_{3}$ & $\mathrm{H}$ & 95 & $3.40^{\circ}$ & 5.05 & 6.45 & $\mathrm{f}$ & 6.96 & - & $\begin{array}{l}5.25(=\mathrm{CH}) \\
5.35(=\mathrm{CH})\end{array}$ \\
\hline $9 \mathbf{a}$ & $\mathrm{CH}_{3}$ & $\mathrm{CH}_{3}$ & 91 & 3.35 & 5.06 & 6.72 & 6.05 & 6.90 & 1.40 & $4.15\left(\mathrm{OCH}_{3}\right)$ \\
\hline $9 b$ & $\mathrm{CH}\left(\mathrm{CH}_{3}\right)_{2}$ & $\mathrm{CH}_{3}$ & 49 & 3.35 & 5.07 & 6.73 & 6.06 & 6.90 & 1.43 & $1.33\left(\mathrm{C}_{(}\left(\mathrm{CH}_{3}\right)_{2}\right)$ \\
\hline $9 \mathrm{c}$ & $\mathrm{CH}_{2} \mathrm{C} \equiv \mathrm{CH}$ & $\mathrm{CH}_{3}$ & 97 & 3.40 & 5.10 & 6.80 & 6.11 & 6.96 & 1.50 & $\begin{array}{l}2.50(\equiv \mathrm{CH}) \\
4.87\left(\mathrm{OCH}_{2}\right)\end{array}$ \\
\hline 9d & $\mathrm{CH}_{2} \mathrm{CH}=\mathrm{CH}_{2}$ & $\mathrm{CH}_{3}$ & 95 & 3.35 & 5.05 & 6.74 & 6.08 & 6.90 & 1.44 & $4.75\left(\mathrm{OCH}_{2}\right)$ \\
\hline $9 \mathrm{e}$ & $\mathrm{CH}_{2} \mathrm{COO}-$ tert $-\mathrm{Bu}$ & $\mathrm{CH}_{3}$ & 70 & 3.32 & 5.07 & 6.80 & 6.10 & 6.88 & 1.42 & $\begin{array}{l}1.40\left({\left.\mathrm{C}\left(\mathrm{CH}_{3}\right)_{3}\right)},\right. \\
5.24\left(\mathrm{OCH}_{2}\right)\end{array}$ \\
\hline
\end{tabular}

a $\mathrm{ABq}, J=18 \mathrm{~Hz}$, except $5 \mathrm{c}$.

b $\mathrm{d}, J=5.5 \mathrm{~Hz}$.

c s.

d br d, $J=11 \mathrm{~Hz}$.

- dd, $J=6$ and $2 \mathrm{~Hz}$.

f Overlapped with phenyl protons. 
ing the $Z$ isomer were concentrated under reduced pressure and the residue was freeze-dried to give $1.15 \mathrm{~g}(33 \%)$ of the $Z$ isomer (6a): The fractions containing the $E$ isomer were worked up similarly to give $143 \mathrm{mg}(4 \%)$ of the $E$ isomer (7a).

The 3-Z- and $E$-butenyl derivatives ( $6 \mathrm{~b}$ and $7 \mathrm{~b}$ ) and 3-vinyl derivative (6c) were prepared by a similar procedure. Physico-chemical properties are summarized in Table 1.

Acylated Products (9): General Procedures Illustrated with the Preparation of Diphenylmethyl 7-[(Z)-2-(2-Tritylaminothiazol-4-yl)-2-methoxyiminoacetamido]-3-(1-propenyl)-3-cephem-4-carboxylate $(9 a)$

To a chilled mixture of (Z)-2-(2-tritylaminothiazol-4-yl)-2-methoxyiminoacetic acid (266 mg, $0.6 \mathrm{mmol})$ and 1-hydroxybenzotriazole hydrate $(92 \mathrm{mg}, 0.6 \mathrm{mmol})$ in THF $(5 \mathrm{ml})$ was added DCC $(124 \mathrm{mg}, 0.6 \mathrm{mmol})$. The mixture was stirred for 2 hours at $5^{\circ} \mathrm{C}$ and filtered to afford the active ester solution. A suspension of $\mathbf{4 a}(221 \mathrm{mg}, 0.5 \mathrm{mmol})$ in EtOAc $(5 \mathrm{ml})$ was shaken with aq $\mathrm{NaHCO}_{3}$ and water, dried and evaporated under reduced pressure. The residue was dissolved in THF (1 ml) and added into the above-prepared active ester solution. The mixture was stirred overnight at room temperature and evaporated under reduced pressure. The residue was dissolved in EtOAc and the mixture was washed with aq $\mathrm{NaHCO}_{3}$ and water. After concentration, the residue was chromatographed on a column of Silica gel (Merck Kieselgel 60,10 g) and the column was eluted with toluene containing $10 \%$ of EtOAc. The fraction containing the desired product was concentrated to dryness to give $380 \mathrm{mg}(91 \%)$ of the title compound. SI-MS $m / z 832(\mathrm{M}+1)^{+}$.

The $O$-substituted derivatives $(9 \mathrm{~b} \sim 9 \mathrm{e})$ were similarly prepared by $N$-acylation of $4 \mathrm{a}$ with the corresponding $N$-tritylated side chain acids $(8 \mathrm{~b} \sim 8 \mathrm{e})$. Data on 9 are summarized in Table 9.

$O$-Substituted Cephalosporins (10): General Procedures Illustrated with the Preparation 7-[( $Z)-2$ (2-Aminothiazol-4-yl)-2-methoxyiminoacetamido]-3-[( $Z$ )-1-propenyl]-3-cephem-4-carboxylic Acid (10a)

A mixture of $9 \mathrm{a}(350 \mathrm{mg}, 0.42 \mathrm{mmol})$ and $85 \%$ formic acid $(2 \mathrm{ml})$ was stirred for 1 hour at room temperature. Hydrochloric acid $(0.1 \mathrm{ml})$ was added and the mixture was stirred for additional 2 hours. The mixture was evaporated under reduced pressure and the residue was chromatographed on a column of $\mathrm{C}_{18}$ Silica gel (the packing of prepPAK-500/ $\mathrm{C}_{18}$ (Waters), $50 \mathrm{ml}$ ). The column was eluted with water, $10 \% \mathrm{MeOH}$ and $20 \% \mathrm{MeOH}$, successively and the fractions were monitored by HPLC. The fractions containing the desired product were combined and concentrated under reduced pressure. The concentrate was freeze-dried to give $62 \mathrm{mg}(35 \%)$ of the product as an amorphous powder. The $O$-substituted acids $(\mathbf{1 0 b} \sim 10 \mathrm{e})$ were prepared by a similar procedure. Physico-chemical data are summarized in Table 2.

Prodrug-type Esters (11): General Procedure Illustrated with the Preparation of 1-Acetoxyethyl 7-[( $Z$ )-2-(2-Aminothiazol-4-yl)-2-hydroxyiminoacetamido]-3-[(Z)-1-propenyl]-3-cephem-4-carboxylate (11a)

To a stirred mixture of $6 \mathrm{a}(1.02 \mathrm{~g}, 2.5 \mathrm{mmol})$ in DMF (4 ml) was added sodium carbonate $(159 \mathrm{mg}$, $1.5 \mathrm{mmol}$ ) and the mixture was stirred for 1 hour at room temperature. The mixture was cooled to $0^{\circ} \mathrm{C}$ and a solution of 1-acetoxyethyl bromide $(501 \mathrm{mg}, 3 \mathrm{mmol})$ in DMF $(2 \mathrm{ml})$ was added dropwise over a period of 15 minutes. The mixture was stirred for 40 minutes at the same temperature and diluted with EtOAc $(100 \mathrm{ml})$. The reaction mixture was washed with water and dried over anhydrous $\mathrm{MgSO}_{4}$. The filtrate was concentrated in vacuo and the residue was chromatographed on a column of Silica gel (Merck Kieselgel 60,50 g). The column was eluted with $\mathrm{CHCl}_{3}-\mathrm{MeOH}(20: 1)$ and the fractions containing the desired product were combined and concentrated under reduced pressure. The residue was triturated with isopropyl ether and $296 \mathrm{mg}(24 \%)$ of 11 a was collected by filtration. The product $(100 \mathrm{mg})$ was crystallized from EtOAc to give $49.6 \mathrm{mg}$ of crystalline 11a: ${ }^{1} \mathrm{H}$ NMR $\left(400 \mathrm{MHz}, \mathrm{DMSO}-d_{6}\right) \delta 1.43$ and $1.44\left(3 \mathrm{H}\right.$, two d, $\left.J=5.5 \mathrm{~Hz}, \mathrm{CHCH}_{3}\right), 1.59$ and $1.60(3 \mathrm{H}$, two dd, $J=1.8$ and $\left.7.0 \mathrm{~Hz}, \mathrm{CH}=\mathrm{CHCH}_{3}\right), 2.05$ and $2.07(3 \mathrm{H}$, two $\mathrm{s}, \mathrm{OAc}), 3.52$ and $3.54(1 \mathrm{H}$, two $\mathrm{d}, J=18$ $\mathrm{Hz}, 2-\mathrm{H}), 3.59$ and $3.61(1 \mathrm{H}$, two d, $J=18 \mathrm{~Hz}, 2-\mathrm{H}), 5.22$ and $5.24(1 \mathrm{H}$, two d, $J=4.8 \mathrm{~Hz}, 6-\mathrm{H}), 5.62 \sim$ $5.74\left(1 \mathrm{H}, \mathrm{m}, \mathrm{CH}=\mathrm{CHCH} \mathrm{CH}_{3}\right), 5.80$ and $5.83(1 \mathrm{H}$, two dd, $J=4.8$ and $8.0 \mathrm{~Hz}, 7-\mathrm{H}), 6.07$ and $6.09(1 \mathrm{H}$, two dd, $J=10.8$ and $\left.1.8 \mathrm{~Hz}, \mathrm{CH}=\mathrm{CHCH}_{3}\right), 6.65$ and $6.66(1 \mathrm{H}$, two s, thiazole- $\mathrm{H}), 6.83$ and $6.93(1 \mathrm{H}$, 
two q, $\left.J=5.5 \mathrm{~Hz}, \mathrm{CHCH}_{3}\right), 7.11\left(2 \mathrm{H}, \mathrm{s}, \mathrm{NH}_{2}\right), 9.45$ and $9.47(1 \mathrm{H}$, two d, $J=8.0 \mathrm{~Hz}, 7-\mathrm{CONH}), 11.291$ and $11.293(1 \mathrm{H}$, two s, NOH).

Compounds 11b 11f were prepared by a similar procedure using pivaloyloxymethyl iodide, 1cyclohexylacetyloxyethyl iodide, 1-ethoxycarbonyloxyethyl iodide, 1-cyclohexyloxycarbonyloxyethyl iodide and (5-methyl-2-oxo-1,3-dioxolen-4-yl)methyl bromide, respectively, instead of 1-acetoxyethyl bromide in 11a and compounds 11e and 11f were crystallized from MIBK and MEK respectively. Physico-chemical properties of $\mathbf{1 1}$ are summarized in Table 3.

Determination of MICs

MICs were determined on solid medium by the standard 2-fold agar dilution method in MuellerHinton agar (Difco) after incubation at $37^{\circ} \mathrm{C}$ for 18 hours with an inoculum size of $10^{\circ} \mathrm{cfu} / \mathrm{ml}$.

\section{Blood Level in Mice}

Male $d d \mathrm{Y}$-mice, weighing 18 to $22 \mathrm{~g}$, were given an antibiotic solution in $10 \%$ DMSO at a dose of $100 \mathrm{mg} / \mathrm{kg}$ by oral, im or iv administration. Blood samples were collected from the orbital sinuses at $0.5,1,2,3,4,5,6$ and 7 hours after oral administration or at 10, 20, 30, 40, 50, 60, 90 and 120 minutes after im or iv administration and assayed by the paper-disc agar diffusion method using Micrococcus luteus PCI 1001 as an assay organism. The esters (11) were administered orally at a dose of $100 \mathrm{mg} / \mathrm{kg}$ equivalent to their parent acid (6a) and their blood levels were assayed and indicated as the concentration of $6 \mathrm{a}$. The half life $\left(\mathrm{T}_{1 / 2}\right.$, hours) and area under the drug concentration-time curve (AUC, $\mu \mathrm{g} \cdot$ hours $/ \mathrm{ml}$ ) were calculated by the method of LeITNER et al ${ }^{19)}$. The relative bioavailability of 11 and cefuroxime axetil was calculated from AUC's after oral administration of these prodrug esters and those after iv administration of parent cephalosporin $6 \mathbf{6}$ and cefuroxime, respectively. The relative bioavailability of cefaclor was calculated from AUC's after oral and iv administrations of cefaclor.

\section{Protective Effect}

Organisms were cultured overnight at $37^{\circ} \mathrm{C}$ in brain heart infusion broth and suspended in $5 \%$ hog mucin (American Laboratory, Omaha, Neb. U.S.A.). Male $d d Y$-mice were infected intraperitoneally with about 100 times of the median lethal dose of the pathogen. Mice were individually given an antibiotic solution in 10\% DMSO at each dose level of $0.16,0.63,2.5$ and $10 \mathrm{mg} / \mathrm{kg}$ orally or intramuscularly just before the bacterial challenge. The $50 \%$ protective dose $\left(\mathrm{PD}_{50}, \mathrm{mg} / \mathrm{kg}\right)$ was calculated by the method of LITCHFIELD and WILCOXON ${ }^{203}$, from survival rate recorded on 7 days after the bacterial infection. The esters 11 were administered at doses equivalent to $\mathbf{6 a}$ and their $\mathrm{PD}_{50}$ values were indicated as $6 \mathbf{a}$.

\section{Acknowledgments}

The authors express their appreciation to Professor M. OHASHr of the University of Electro-Communications for the mass spectral data. They also wish to thank Dr. T. Tsuno and his associates of the Analytical Chemistry Laboratory of this Institute for the microanalytical and spectral data.

\section{References}

1) Harding, S. M.; P. E. O. Williams \& J. Ayrton: Pharmacology of cefuroxime as the 1-acetoxyethyl ester in volunteers. Antimicrob. Agents Chemother. 25: 78 82, 1984

2) Sadaki, H.; H. Imaizumi, T. Inaba, T. Hirakawa, Y. Murotani, Y. Watanabe, S. Minami \& I. SaiKAWA: Studies on $\beta$-lactam antibiotics for medicinal purpose. XVIII. Synthesis and structure-activity relationships of $7 \beta-[(Z)-2-(2$-aminothiazol-4-yl)-2-methoxyiminoacetamido]-3-substituted methyl-3-cephem4-carboxylic acid derivatives. Yakugaku Zasshi (Japan) 106: 129 146, 1986

3) ANGehrn, P.; R. Rfiner \& P. Hohl: Ro 15-8075, a new orally active cephalosporin: Bacteriological evaluation. Program and Abstracts of the 25th Intersci. Conf. on Antimicrob. Agents Chemother., No. 578, p. 198, Minneapolis, Sept. 29 Oct. 2, 1985

4) KuCK, N. A.; W. V. Curran \& R. T. Testa: Antibiotic activity of CL 118,673, a new oral cephalosporin. In Recent Advances in Chemotherapy. Antimicrobial Section 2. Ed., J. IsHigam, pp. 1137 1138, Uni- 
versity of Tokyo Press, Tokyo, 1985

5) Inove, M.; A. Tamura, T. Yoshida, R. Okamoto, K. Atsumi, K. Nishihata \& S. Mitsuhashi: A novel oral cephalosporin, ME1207 - in vitro and in vivo activities. Program and Abstracts of the 25th Intersci. Conf. on Antimicrob. Agents Chemother., No. 582, p. 199, Minneapolis, Sept. $29 \sim$ Oct. 2, 1985

6) Fujimoto, K.; S. Ishihara, H. Yanagisawa, J. Ide, E. Nakayama, H. Nakao, S. Sugawara \& M. Iwata: Studies on orally active cephalosporin esters. J. Antibiotics 40:370 384, 1987

7) Yoshimura, Y.; N. Hamaguchi \& T. Yashiki: Preparation of 1-acyloxyethyl esters of 7-[2-(2-aminothiazol-4-yl)acetamido]-3-[1]1-(2-dimethylaminoethyl)- $1 H$-tetrazol-5-yl]thio]methyl]ceph-3-em-4-carboxylic acid (cefotiam) and their oral absorption in mice. J. Antibiotics 39: 1329 1342, 1986

8) Nishimura, T.; Y. Yoshimura, A. Mryake, M. Yamaoka, K. Takanohashi, N. Hamaguchi, S. Hirat, T. YAshiki \& M. Numata: Orally active 1-(cyclohexyloxycarbonyloxy)alkyl ester prodrugs of cefotiam. J. Antibiotics 40:81 90, 1987

9) Natto, T.; H. Hoshi, S. Aburaki, Y. Abe, J. Okumura, K. Tomatsu \& H. Kawaguchx: Synthesis and structure-activity relationships of a new oral cephalosporin, BMY-28100 and related compounds. J. Antibiotics 40: $991 \sim 1005,1987$

10) Tomatsu, K.; S. Ando, S. Masuyoshi, S. Kondo, M. Hirano, T. Miyaki \& H. Kawaguchi: In vitro and in vivo evaluations of BMY-28100, a new oral cephalosporin. J. Antibiotics 40: 1175 1183, 1987

11) Naito, T.; S. Aburaki, H. Kamachi, Y. Narita, J. Okumura \& H. Kawaguchi: Synthesis and structure-activity relationships of a new series of cephalosporins, BMY-28142 and related compounds. J. Antibiotics 39: 1092 1107, 1986

12) Bucourt, R.; R. Heymes, A. Lutz, L. Pénasse \& J. Perronnet: Cephalosporins a chaines amino-2 thiazolyl-4 acetyles. Tetrahedron 34:2233 2243, 1978

13) Yamanaka, H.; T. Chiba, K. Kawabata, J. Takasugi, T. Masugi \& T. Takaya: Studies on $\beta$-lactam antibiotics. IX. Synthesis and biological activity of a new orally active cephalosporin, cefixime (FK027). J. Antibiotics 38: 1738 1751, 1985

14) Takaya, T.; T. Kamimura, Y. Watanabe, Y. Matsumoto, S. Tawara, F. Shibayama, Y. Mine \& S. KUWAHARA: FK482, a new orally active cephalosporin: In vitro antibacterial activity. Program and Abstracts of the 27th Intersci. Conf. on Antimicrob. Agents Chemother., No. 652, p. 210, New York, Oct. $4 \sim 7,1987$

15) Mine, Y.; Y. Yokota, T. Kamimura, S. TAWARA \& F. Shibayama: FK482, a new orally active cephalosporin: In vivo antibacterial activity. Program and Abstracts of the 27th Intersci. Conf, on Antimicrob. Agents Chemother., No. 653, p. 210, New York, Oct. 4 7, 1987

16) Bucourt, R.; R. Heymes, J. Perronnet, A. Lutz \& L. Penasse: Influence de la substitution de l'oxime sur l'activite antibacterienne dans la serie du cefotaxime. Eur. J. Med. Chem. Chim. Ther. 16: 307 316, 1981

17) BuCKLEY, E. \& E. Whittle: Some reactions involved in the photobromination of simple alcohols and ketones in the vapor phase. Can. J. Chem. 40:1611 1615, 1962

18) Sakamoto, F.; S. Ikeda \& G. Tsukamoto: Studies on prodrugs. II. Preparation and characterization of (5-substituted-2-oxo-1,3-dioxolen-4-yl)methyl ester of ampicillin. Chem. Pharm. Bull. 32: 2241 2248, 1984

19) Leitner, F.; T. A. Pursiano, R. E. Buck, Y. H. Tsai, D. R. Chisholm, M. Misiek, J. V. Desiderio \& R. E. KESSLER: BMY-28100, a new oral cephalosporin. Antimicrob. Agents Chemother. 31: 238 243, 1987

20) Litchfield, J. T. \& F. Wilcoxon: Simplified method of evaluating dose effect experiments. J. Pharmacol. Exp. Ther. 96: 99 113, 1949 